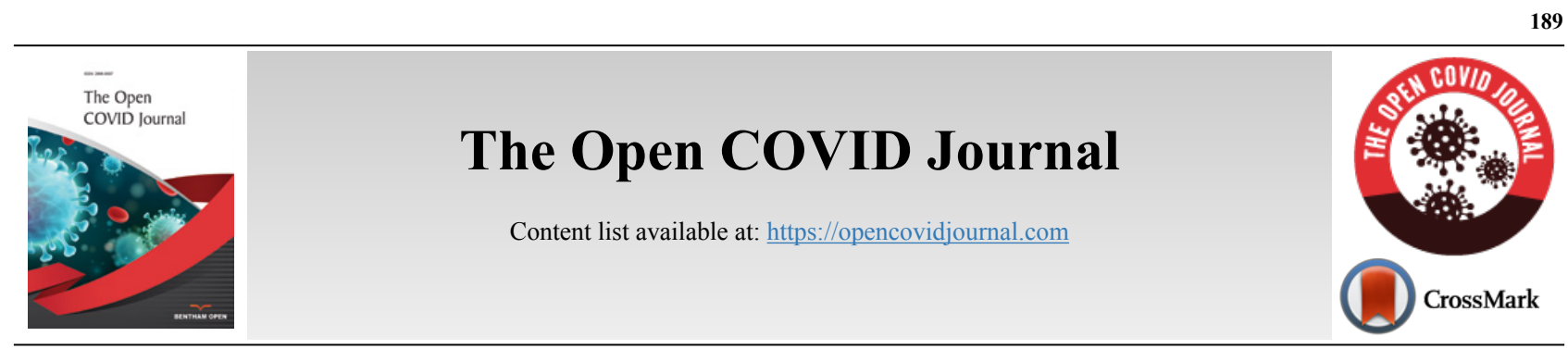

\title{
EDITORIAL
}

\section{Black Cumin in Fighting with Coronaviruses}

\author{
Asaduzzaman $\operatorname{Khan}^{1, *}$ \\ ${ }^{I}$ The Research Center for Preclinical Medicine, Southwest Medical University, Luzhou, Sichuan, 646000, China
}

\begin{tabular}{|l|l|l|l|} 
Article History & Received: July 19, 2021 & Revised: September 21, 2021 & Accepted: September 21, 2021 \\
\hline
\end{tabular}

The recent pandemics caused by the coronaviruses have become major threats for human species in the twenty first century, especially the novel coronavirus disease (COVID-19) caused by SARS-CoV-2 has serious effects on human health and normal lifestyles across the globe with heavy death tolls. Till today $\left(20^{\text {th }}\right.$ June, 2021), a total of $178,936,640$ cases have been officially reported, with $3,874,801$ cases of death due to COVID-19 across the world [1]. Two previous pandemics of this century were Severe Acute Respiratory Syndrome (SARS) and Middle East Respiratory Syndrome (MERS), which were caused by coronaviruses SARS-CoV/MERS-CoV infections, and emerged in 2002 and 2012 respectively. In all of the three cases of pandemics, the respiratory tract is the site of infection with fatal consequences [2 - 4]. Since the beginning of COVID-19, different drugs have been used, and nowadays, several vaccines are in use to fight against this deadly disease, but still no complete cure [5]. Natural products, especially from plants and herbs have been used for medicinal purposes for thousands of years in different parts of the world. In fact, it is thought that $80 \%$ of the world population are dependent on traditional medicines based on natural products. Studies revealed that different natural products or medicinal plants are effective against viral diseases, and more specifically, what we discuss here, their potential against recent viral pandemics are well documented [4].

Black cumin (Nigella sativa) has a long history of being used for medicinal purposes traditionally, mainly in Arabaian, African, South Asian and some parts of East Asian countries. In this COVID-19 pandemic situation, I found many rural people relying on black cumin to keep themselves healthy, but certainly, there are little scientific works on black cumin against COVID-19 and other coronavirus causing diseases. Although few, there remain scientific evidences that black cumin is effective against coronaviruses. For example, extracts of black cumin were found to suppress the virus load through

\footnotetext{
* Address correspondence to this author at the The Research Center for Preclinical Medicine, Southwest Medical University, Luzhou, Sichuan, 646000, China; Tel: +8619111859312 ;

E-mail: asadkhanbmj@yahoo.com,asadkhan@swmu.edu.cn
}

the induction of interleukin 8 (IL-8), and thus interfere with the replication of coronaviruses [6]. Black cumin supplementation is speculated to be beneficial for improving the conditions of COVID-19 patients, and it can be used in combination along with repurposed conventional drugs for the management of COVID-19 patients [7]. A phase III clinical investigation (NCT04347382) has been performed against COVID-19 recently, where the patients were given a mixture of black cumin powder $(80 \mathrm{mg} / \mathrm{Kg} /$ day $)$ and natural honey (1 $\mathrm{gm} / \mathrm{kg} / \mathrm{day}$ ) for 14 days orally, but the result is yet to come out [8]. Usually in any kind of infection, $\mathrm{Zn}$ can improve both of innate and adaptive immunity, and bioactive components of black cumin might act as ionophores, so the combination of black cumin and $\mathrm{Zn}$ supplementation is also supposed to be beneficial for COVID-19 patients [9].

Thymoquinone is one of the major ingredients of black cumin, and this natural product is a strong candidate for drug development against coronaviruses, including SARS-CovV-2 [10]. Thymoquinone is well-known for its immune-modulatory role, which is probably associated with its anti-viral effects. In an in vitro study, $\mathrm{Xu}$ et al. [11] found that thymoquinone can inhibit SARS-CoV and SARS-CoV-2 by binding with the human angiotensin-converting enzyme 2 (ACE2), thus blocking the viral entry into host cells. Molecular docking and molecular dynamics simulation study also indicated thymoquinone as a potential inhibitor of ACE2 [12]. The broad spectrum antimicrobial activity of thymoquinone could also be beneficial to minimize secondary infections in COVID-19 patients [13].

There are some recent reviews discussing the possible beneficial role of black cumin or thymoquinone against COVID-19 [14, 15], but the exact molecular mechanism of thymoquinone action against coronaviruses or in COVID-19 patients is not yet clear. However, from preclinical studies and clinical trials as well as the history of traditional medicinal usage, it is clear that black cumin or its major component thymoquinone is a potential candidate of drug development to fight against coronaviruses, especially against SARS-CoV-2 causing deadly COVID-19. There should be more focus on 
black cumin and thymoquinone research in coronavirus or COVID-19 studies.

\section{REFERENCES}

[1] Worldometer. Coronavirus Cases. Available at: https://www.worldometers.info/coronavirus/

[2] de Wit E, van Doremalen N, Falzarano D, Munster VJ. SARS and MERS: recent insights into emerging coronaviruses. Nat Rev Microbiol 2016; 14(8): 523-34.

[http://dx.doi.org/10.1038/nrmicro.2016.81] [PMID: 27344959]

[3] Zhu N, Zhang D, Wang W, et al. A novel coronavirus from patients with pneumonia in china, 2019. N Engl J Med 2020; 382(8): 727-33. [http://dx.doi.org/10.1056/NEJMoa2001017] [PMID: 31978945]

[4] Shawon J, Akter Z, Hossen MM, et al. Current landscape of natural products against coronaviruses: Perspectives in COVID-19 treatment and anti-viral mechanism. Curr Pharm Des 2020; 26(41): 5241-60. [http://dx.doi.org/10.2174/1381612826666201106093912] [PMID: 33155902]

[5] Khan MA, Bin Islam S, Rakib MU, et al. Major drugs used in COVID-19 treatment: Molecular mechanisms, validation and current progress in trials. Coronaviruses 2020. Epub ahead of prin [http://dx.doi.org/10.2174/2666796701999201204122819]

[6] Ulasli M, Gurses SA, Bayraktar R, et al. The effects of Nigella sativa (Ns), Anthemis hyalina (Ah) and Citrus sinensis (Cs) extracts on the replication of coronavirus and the expression of TRP genes family. Mol Biol Rep 2014; 41(3): 1703-11.

[http://dx.doi.org/10.1007/s11033-014-3019-7] [PMID: 24413991]

[7] Maideen NMP. Prophetic Medicine-Nigella Sativa (Black cumin seeds) - Potential herb for COVID-19? J Pharmacopuncture 2020; 23(2): $62-70$.
[http://dx.doi.org/10.3831/KPI.2020.23.3.179] [PMID: 32685234]

[8] ClinicalTrials.gov. Honey \& Nigella sativa trial against COVID-19. Identifier: NCT04347382 2020. Avaialable from: https://clinicaltrials.gov/ct2/show/study/NCT04347382

[9] Rahman MT. Potential benefits of combination of Nigella sativa and Zn supplements to treat COVID-19. J Herb Med 2020; 23: 100382. [http://dx.doi.org/10.1016/j.hermed.2020.100382] [PMID: 32834942]

[10] Sommer AP, Försterling HD, Naber KG. Thymoquinone: Shield and sword against SARS-CoV-2. Precis Nanomed 2020; 3(3): 541-8. [http://dx.doi.org/10.33218/001c.12984]

[11] Xu H, Liu B, Xiao Z, et al. Computational and experimental studies reveal that thymoquinone blocks the entry of coronaviruses into in vitro cells. Infect Dis Ther 2021; 10(1): 483-94. [http://dx.doi.org/10.1007/s40121-021-00400-2] [PMID: 33532909]

[12] Srivastava N, Garg P, Srivastava P, Seth PK. A molecular dynamics simulation study of the ACE2 receptor with screened natural inhibitors to identify novel drug candidate against COVID-19. PeerJ 2021; 9: e11171.

[http://dx.doi.org/10.7717/peerj.11171] [PMID: 33981493]

[13] Khan MA, Younus H. Potential implications of black seed and its principal constituent Thymoquinone in the treatment of COVID-19 patients. Curr Pharm Biotechnol 2020. Epub ahead of print [http://dx.doi.org/10.2174/1389201021999201110205048] [PMID: 33176642]

[14] Khazdair MR, Ghafari S, Sadeghi M. Possible therapeutic effects of Nigella sativa and its thymoquinone on COVID-19. Pharm Biol 2021; 59(1): 696-703.

[http://dx.doi.org/10.1080/13880209.2021.1931353]

[PMID: 34110959]

[15] Badary OA, Hamza MS, Tikamdas R. Thymoquinone: A promising natural compound with potential benefits for COVID-19 prevention and cure. Drug Des Devel Ther 2021; 15: 1819-33. [http://dx.doi.org/10.2147/DDDT.S308863] [PMID: 33976534]

\section{C) 2021 Asaduzzaman Khan}

This is an open access article distributed under the terms of the Creative Commons Attribution 4.0 International Public License (CC-BY 4.0), a copy of which is available at: https://creativecommons.org/licenses/by/4.0/legalcode. This license permits unrestricted use, distribution, and reproduction in any medium, provided the original author and source are credited. 